Dunamis: Jurnal Teologi dan Pendidikan Kristiani

Volume 5, Nomor 1 (Oktober 2020)

ISSN 2541-3937 (print), 2541-3945 (online)

http://www.sttintheos.ac.id/e-journal/index.php/dunamis

DOI: 10.30648/dun.v5i1.397

Submitted: 13 Juli 2020

Accepted: 30 September 2020

Published: 24 Oktober 2020

\title{
From Conservative Turn to Non-Violence Politics: Theo-Politik Salib John Howard Yoder
}

\author{
Andreas Kristianto \\ Program Pascasarjana Teologi Universitas Kristen Duta Wacana \\ andreassiwi1305@gmail.com
}

\begin{abstract}
The Reformation era was recorded as an era of democracy that was marked by various violence acts in the name of religion. This violence was caused by the rise of religious conservatism (conservative turn). In this context, the writer wants to offer an alternative solution through the theo-politics of the cross of John Howard Yoder, a US Mennonite figure. The result of this study was that the theo-politics of the cross builds a consciousness that can counter the consciousness that comes from religious conservatism, but by means of non-violence. The theo-politics of the cross builds an alternative community that shows a friendly face of the church and solidarity with the marginal people.
\end{abstract}

Keywords: violence; peace; conservatism; solidarity; hospitality

\begin{abstract}
Abstrak
Era Reformasi tercatat sebagai era demokrasi yang diwarnai dengan berbagai tindak kekerasan atas nama agama. Kekerasan atas nama agama ini disebabkan oleh bangkitnya konservatisme agama (conservative turn). Dalam konteks ini, penulis hendak menawarkan solusi alternatif melalui theo-politik salib John Howard Yoder, seorang tokoh Mennonite Amerika Serikat. Hasil dari kajian ini adalah bahwa theo-politik salib membangun suatu kesadaran yang dapat melawan kesadaran yang bersumber pada paham konservatisme agama, namun dengan jalan tanpa kekerasan. Theo-politik salib membangun komunitas alternative yang menampilkan wajah gereja yang ramah, dan solider terhadap kaum marjinal.
\end{abstract}

Kata Kunci: kekerasan; perdamaian; konservatisme; solidaritas; keramahtamahan 


\section{PENDAHULUAN}

Kekerasan agama di satu sisi memperlihatkan kompleksitas yang rumit antara trauma historis, perbedaan politik, etnis, budaya dan ketidakadilan ekonomi, tetapi di sisi lain juga memperlihatkan adanya persoalan spiritualitas berkaitan dengan "kegelisahan eksistensial" yang muncul dari kebutuhan untuk mendefinisikan identitas seseorang berdasarkan agama/tradisi tertentu. Pengalaman kekerasan ini, secara eksistensial membentuk pemahaman diri (internal) berhubungan dengan dunia, dimana komunitas (baca: gereja) berpijak. Secara masif, memori kekerasan di zaman orde baru menjadi ingatan yang kuat dalam pembentukan identitas diri maupun komunitas Kristiani.

Gerakan konservatisme Islam di Indonesia mengalami pertumbuhan dan perkembangan yang tidak terduga dalam lima tahun terakhir. ${ }^{1}$ Tentunya, dampak negatif yang terjadi adalah adanya "impotensi" keberlangsungngan demokrasi dan keutuhan bangsa sebagai negara majemuk. Beberapa yang muncul adalah gerakan

\footnotetext{
1 Amin Maghfuri, "Countering ConservativeRadical Understanding by Mainstreaming Moderat Islam and the Role of Educational Institution in Indonesia," Sunan Kalijaga International Journal on Islamic Educational Research 3, no. 1 (December 16, 2019): 1-14, accessed October 22, 2020, http:// ejournal.uin-suka.ac.id/tarbiyah/index.php/SKIJIER /article/view/2782.
}

tarbiyah, Hizbut Tahrir Indonesia (HTI), Majelis Mujahidin Indonesia (MMI), Front Pembela Islam (FPI) dan lain-lain. ${ }^{2}$ Munculnya ormas-ormas berbasis Islam ini secara masif membentuk gelombang baru dalam mengiringi proses demokratisasi di Indonesia. Gerakan ini dipahami bukan soal upaya mengislamkan warga Indonesia (islamisasi) saja, melainkan juga sebagai upaya menerapkan syariat Islam dengan menampilkan segala atribut dan simbol keagamaan melalui aksi kultural, keagamaan, dan konstitusional (hukum). Beberapa aksi intoleran dan kekerasan terbukti dilakukan oleh kelompok-kelompok yang berafiliasi dengan organisasi fundamentalis maupun konservatif, baik untuk menerapkan hukum islam secara formal ataupun untuk mendirikan khilafah Islamiyah yang berarti menggantikan ideologi Pancasila.

Tantangan yang semakin meningkat terlihat dari bangkitnya konservatisme yang mengarah pada kekerasan atas nama agama. Tamawiwy mengatakan bahwa aksi teror Surabaya 2018 dipandang sebagai persoalan agama/ teologis. ${ }^{3}$ Persoalan ketidak-

\footnotetext{
2 Sri Yunanto, Islam Moderat vs Islam Radikal: Dinamika Politik Islam Kontemporer (Yogyakarta: Media Pressiondo, 2018), 97.

3 August Corneles Tamawiwy, "Bom Surabaya 2018: Terorisme Dan Kekerasan Atas Nama Agama," GEMA TEOLOGIKA: Jurnal Teologi Kontekstual dan Filsafat Keilahian 4, no. 2 (October 16, 2019): 175-194, accessed October 22, 2020,
} 
adilan sosial, ekonomi dan politik bukanlah satu-satunya faktor terkuat yang mampu mendorong para teroris untuk mati demi memperjuangkan identitas kelompoknya yang tertindas, ada sesuatu yang lebih besar, yang lebih luhur, yang berada di luar sejarah dan bersifat metafisik. Aksi kekerasan atas nama agama ini menunjuk-kan ancaman yang serius dari kebangkitan conservative turn dalam perkembangan demokrasi di Indonesia. Bruinessen menyatakan bahwa tumbuhnya Islam konservatif pada dasarnya karena sebagian besar Muslim di Indonesia sudah memiliki pandangan konservatif sebelumnya. ${ }^{4}$ Hasil survei menunjukkan bahwa $72 \%$ muslim di Indonesia memiliki keinginan besar untuk menerapkan syariah sebagai hukum formal/ resmi negara. ${ }^{5}$ Meskipun survei ini tidak sepenuhnya benar, karena mayoritas muslim Indonesia dikenal sebagai masyarakat yang toleran, tetapi hasil tersebut dapat menjadi kajian refleksi dan analisis dalam keberlangsungan agama dalam pergulatan politik di Indonesia. Indikasinya, juga terlihat dari beberapa kasus yang melibatkan unsur politik, misalnya pada Pilgub DKI

http://journal-theo.ukdw.ac.id/index.php/gemateolo gika/article/view/443.

4 Muhammad Zuhdi, "Challenging Moderate Muslims: Indonesia's Muslim Schools in the Midst of Religious Conservatism," Religions 9, no. 10 (October 11, 2018): 310, accessed October 22, 2020 , http://www.mdpi.com/2077-1444/9/10/310.
Jakarta tahun 2017 serta Pilpres 2019. Mobilisasi massa yang berulang-ulang dengan penggunaan atribut bercirikan Islam dalam aksi-aksi tersebut jelas menunjukkan keberhasilan konservatif dalam meraih simpati dan memperluas pengaruhnya.

Titik awal bahaya pemahaman konservatif adalah ketika dibarengi dengan pemahaman ekstrem, di mana pandangannya yang tidak menerima perbedaan, baik pemahaman, keyakinan, dan lain sebagainya. Riset terbaru dari Mietzner \& Muhtadi yang berjudul The Myth of Pluralism: Nahdlatul Ulama and the Politics of Religious Tolerance in Indonesia (2020), memperlihatkan bahwa para pengikut NU umumnya tidak toleran terhadap minoritas agama, seperti penduduk muslim lainnya. Pluralisme hanya dipandang sebagai alat mobilisasi pemilu untuk pencarian kekuasaan NU daripada ide untuk mempertahankan norma-norma masyarakat yang majemuk. Meskipun dalam pengamatan yang terjadi NU hanya merangkul orang Kristen dan non-Muslim sebagai posisi politik yang strategis. Banyak pengikut NU yang tidak menginginkan rumah ibadah non-muslim

\footnotetext{
5 Alex P. Schmid, "Moderate Muslims and Islamist Terrorism: Between Denial and Resistance," The International Centre for Counter-Terrorism - The Hague 8, no. 9 (2017), accessed October 22, 2020, https://icct.nl/publication/moderate-muslims-andislamist-terrorism-between-denial-and-resistance/.
} 
ada di lingkungan sekitar mereka atau memilih gubernur non-muslim. Hal ini juga berlaku perihal sikap pengikut NU terhadap etnis Tinghoa, mereka dipandang sebagai saudara anak bangsa dalam konteks persaingan melawan kelompok-kelompok Islamis (konservatif). Mietzner \& Muhtadi memperlihatkan hawa perlindungan yang ditawarkan oleh komunitas NU kepada kelompok minoritas hanya bersifat taktis dan cenderung keropos (tidak berkelanjutan). ${ }^{6}$

Dari pengamatan di atas, tulisan ini bertujuan untuk menggali teologi politik yang kontekstual di tengah merebaknya persoalan intoleransi dan kekerasan atas nama agama di Indonesia. Apa yang harus dilakukan gereja (komunitas Kristen) dalam menanggapi realitas kekerasan ini? Bagaimana teologi politik Kristen berperan dan memberikan sumbangsih di tengah masyarakat? Dengan penggalian visi theo-politik yang kontekstual, ada kontribusi terkait soal nilai-nilai, etika, dan kebajikan yang bersumber dari tradisi Kristiani dalam pergulatannya di tengah masyarakat Indonesia.

\section{METODE PENELITIAN}

Tulisan ini menggunakan metode penelitian literer atau studi pustaka, yang

\footnotetext{
${ }^{6}$ Marcus Mietzner and Burhanuddin Muhtadi, "The Myth of Pluralism: Nahdlatul Ulama and the Politics of Religious Tolerance in Indonesia," Contemporary Southeast Asia: A Journal of International and
}

dikaji secara analitis dan argumentatif. Topik dibahas menggunakan pustakapustaka baik dalam bentuk buku maupun jurnal. Penulis hendak mengkaji pandangan seorang tokoh yaitu teolog Mennonite John Howard Yoder, khususnya berkaitan dengan teologi politik yang dibangun atas dasar peristiwa salib. Bagaimana teologi salib berdampak dan mempengaruhi teologi politik? Apa implikasinya bagi peran politik gereja di masa kini? Melalui analisis dari Yoder, penulis berusaha untuk menempatkan titik pijak salib dan penderitaan Kristus dalam konteks diskriminasi dan kekerasan atas nama agama di Indonesia.

Ada beberapa pertimbangan pemilihan teologi politik John Howard Yoder sebagai pisau bedah dalam kajian ini. Pertama, masalah yang dihadapi teologi politik dan etika sosial akhir-akhir ini adalah meningkatnya kekerasan dan diskriminasi, dan karena itu menjadikan suatu kebutuhan untuk berteologi secara ekumenis. Yoder adalah seorang Mennonite yang bekerja di Amerika Serikat yang memiliki pandangan yang luas dan pengalamannya dalam isu-isu sosial dan politik. Kedua, politik salib adalah model untuk berbicara tentang sisi kemanusiaan Yesus.

Strategic Affairs 42, no. 1 (2020): 58-84, accessed October 22, 2020, https://muse.jhu.edu/article/ $754323 /$ summary. 
Secara teologis, Allah mengalami penyiksaan dan dipermalukan sebagai korban. Karena itu, penulis berangkat dari perspektif "bawah," mencoba melihat dari perspektif korban sejarah yang tampaknya tidak berdaya dalam kekuatan/dominasi imperialisme Romawi. Ketiga, John Howard Yoder memperlihatkan pentingnya salib dalam teologi politik yang menjadi analisis terkait soal aspek politik, budaya, sosial dan ekonomi. Penulis menggunakan kajian tulisan Yoder yang sangat monumental yaitu Politics of Jesus (1994).

\section{HASIL DAN PEMBAHASAN}

\section{Akar Kebangkitan "Conservative Turn" dan Kekerasan di Indonesia}

Pertanyaannya adalah mengapa agama berkontribusi dalam kekerasan di Indonesia? Mujiburrahman melihat bahwa baik orang Islam dan Kristen mengalami perasaan keterancaman. ${ }^{7}$ Ada ketakutan yang diproyeksikan tentang adanya kristenisasi dan ketakutan Kristen terhadap proyeksi Negara Islam. Oleh sebab itu, persoalan konversi (perpindahan agama) menjadi persoalan pelik di tengah relasi

\footnotetext{
7 Mujiburrahman, FeelingThreatened: MuslimChristian Relations in Indonesia's New Order (Leiden: Amsterdam University Press, 2006), 252.

${ }^{8}$ Noorhaidi Hasan, Laskar Jihad: Islam, Militancy, and the Quest for Identity in Post-New Order Indonesia (New York: Southeast Asia Program Cornell University, 2006), 31-61.

${ }^{9}$ Ibid, 219.
}

antara Kristen dan Islam. Sampai sekarang, komunitas Islam politik yang masih terbentuk adalah Laskar Jihad yang pasca Orde Baru menjadi manifestasi radikalisme Islam. ${ }^{8}$ Hal ini masih eksis sampai sekarang karena faktor globalisasi dimana faktor aliran Wahabi di Arab Saudi begitu kuat. Hal ini ditandai sebagai kebangkitan politik Islam, yang menekankan militansi agama dan menjadi kontestasi persaingan dengan nilai-nilai yang dianut bersama yaitu demokrasi dan pluralisme pasca Orde Baru. Terciptanya Laskar Jihad menjadi manifestasi radikal dari politik Islam yang menegaskan persaingan implementasi syariah versus pengembangan demokrasi. ${ }^{9}$

Dalam riset Amos Sukamto, konflik Kristen dan Islam terjadi dikarenakan beberapa analisa. ${ }^{10}$ Pertama, adanya perasaan ketidakpuasan di kalangan muslim. Ketidakpuasan ini berkembang menjadi politis dan menebarkan solidaritas dan keyakinan bahwa amarah yang dirasakan tidak hanya mengguncang faktor individu tetapi juga menyangkut kolektif secara keseluruhan. Kedua, persoalan kristenisasi. Kristenisasi menjadi isu yang mendominasi persepsi

\footnotetext{
${ }^{10}$ Amos Sukamto and Rudy Pramono, "The Roots of Conflicts between Muslims and Christians in Indonesia in 1995-1997," Transformation: An International Journal of Holistic Mission Studies 37, no. 3 (July 11, 2020): 208-221, accessed October 22, 2020, http://journals.sagepub.com/doi/10.1177/ 0265378820937722.
} 
tokoh-tokoh Islam sejak zaman penjajahan. Setelah Indonesia merdeka, persoalan ini tidak kunjung selesai, bahkan sebelum tahun 1965 beredar pamflet yang berisi tentang program kristenisasi di Jawa dan seluruh Indonesia. Misalnya penggunakan perumahan sebagai sarana peribadahan kemudian berubah menjadi fungsi gereja dan mengirim anak-anak muslim ke sekolah-sekolah Kristen secara gratis. Ketiga, kebijakan publik yang justru memperburuk masalah relasi Kristen dan Islam, misalnya dengan RUU Perkawinan 1973, Keputusan Menteri Agama No. 70 tahun 1978 tentang pedoman penyebaran agama, dll. Kebijakan ini dipandang oleh kelompok Kristen lebih menguntungkan kelompok Islam sedangkan kelompok Islam menganggap kebijakan tersebut wajar karena harus melindungi dan mendengar suara mayoritas. Tarik ulur ini menjadi faktor sendiri dalam menambah kebencian antara relasi Kristen dan Islam.

Hasan mengatakan bahwa mayoritas muslim Indonesia tetap toleran dan menentang penggunaan kekerasan, apalagi berkaitan dengan tindakan terorisme, yang semua ini justru mendorong muslim mayoritas bekerja secara lebih sistematis dalam penegakan demokrasi, kesetaraan gender,

${ }^{11}$ Hasan, Laskar Jihad: Islam, Militancy, and the Quest for Identity in Post-New Order Indonesia, 220. dan hak asasi manusia. ${ }^{11}$ Krisis nasional rezim Orde Baru mengungkapkan bahwa persoalan politik mengalami tumpang tindih dengan perubahan dan tantangan wilayah di wilayah lokal. Terlebih lagi era desentralisasi ini otonomi daerah dan lemahnya kepemimpinan daerah sering dianggap sebagai akar penyebab konflik. Hefner mengatakan bahwa dalam penguatan daerah, komunitas warga negara memiliki fungsi untuk menjaga ruang publik dan menjadi aspirasi rakyat. ${ }^{12}$ Elemenelemen ini menjadi penting dalam pembentukan Islam dan demokrasi warga negara yang saling berhubungan satu dengan yang lain. Di sinilah agama berperan untuk menjaga dan merayakan perbedaan di tengah masyarakat.

\section{Theo-Politik Yesus menurut John}

\section{Howard Yoder}

Theo-Politik Salib: “The Obedient NonResistance of Jesus"

Gereja bagi Yoder adalah komunitas minoritas yang unik, yang ditandai dengan adanya pengakuan iman yang kuat, dengan iman kepada Yesus Kristus sebagai Tuhan. Definisi ini di keseluruhan masyarakat sudah lama sekali absen/tidak menjadi

12 Robert W. Hefner, Civil Islam: Muslims and Democratization in Indonesia (Princeton and Oxford: Princeton University Press, 2000), 115. 
pengakuan iman. ${ }^{13}$ Teologi Yoder begitu signifikan berpengaruh dalam gereja-gereja di Amerika. Mengapa? Karena etika politik Yoder didasarkan pada ketaatan tanpa kompromi kepada Yesus Kristus sebagai Tuhan yang tersalib dan mengeksplorasi secara radikal keteladannya di tengah dunia. ${ }^{14}$ Tidak hanya berbasis pada etika kemanusiaan secara umum, tetapi berpijak kepada keteladanan Yesus secara radikal. Bagi Yoder, teologi inkarnasi menjadi pewahyuan tertinggi dari sifat Allah dalam upaya-Nya berada pada sejarah dunia. Salib adalah puncak dan hasil yang tak terhindarkan dari tindakan Yesus yang mengajarkan nilai kepada dunia serta memiliki makna pewahyuan tertinggi. Salib tidak boleh menjadi simbol ahistoris tentang pengorbanan yang terjadi di masa lampau, atau sekedar sebagai hukuman yang menggantikan dosa manusia (substitusi) saja atau hanya sebagai simbol tentang keberdosaan manusia yang menyedihkan.

Yoder mengkritik pandangan Anselmus bahwa pembicaraan kristologinya tidak banyak bicara tentang pemuridan dan ketaatan. Dengan model begini, baginya Yesus secara historis tidak cukup memberi relevansi dalam dunia ini. Padahal kita

\footnotetext{
${ }^{13}$ John Howard Yoder, The Politics of Jesus (Grand Rapids: Eerdmans, 1994), 108.

${ }^{14}$ Ibid, 10
}

mengetahui bahwa salib terjadi dalam realitas sosial Palestina. Janji dan tindakan Yesus yang menyinggung pihak yang berwenang dan menyebabkan mereka membunuhnya. ${ }^{15}$ Yoder memasukkan tema-tema yang diabaikan oleh Anselmus, yaitu berkaitan dengan cara pandang melihat Yesus sebagai manusia, sebagai tokoh sosial, guru, dan figur moral. Yesus bertindak dalam situasi politik dan budaya Palestina. Pembicaraan-Nya tentang Kerajaan Allah, mengampuni manusia, pengajaran-Nya, memberi perintah kepada murid-Nya sebagai perutusan misi di tengah dunia. Yoder juga menekankan bahwa soteriologi (ajaran keselamatan) integral dengan pemuridan salib. Kesatuan ini menghubungkan kesatuan ketaatan kita dengan pekerjaan Allah di dalam Kristus, salib-Nya dengan salib kita dan kematianNya dengan kehidupan kita yang menderita di tengah dunia. Yoder melihat bahwa pertama, persekutuan yang sejati dengan Allah di dalam Kristus diperlukan bagi orang-orang percaya, yang dinyatakan dalam istilah 'persatuan iman', tinggal di dalam Aku' dan 'di dalam Kristus'. Kedua, cara Allah mengatasi kejahatan adalah dengan cara kasih Agape yang mengeks-

15 John Howard Yoder, Preface to Theology, Christology and Theological Method (Elkard: Co-op Bookstore, 1982), 224. 
presikan dirinya dalam budaya non-resistensi (tidak melawan); dan ketiga, adanya pemisahan yang tegas antara gereja dan dunia.

Yoder melihat Yesus sebagai manusia yang memiliki ketaatan yang sempurna, hidup dalam persekutuan dengan Tuhan dan mencintai manusia dengan kasih Agape. Istilah yang dipakai oleh Yoder adalah the obedient non-resistance of Jesus, di mana Yesus melakukan tindakan nonperlawanan, di mana Ia justru menunjukkan kepenuhan Agape Illahi dalam menghormati setiap kebebasan manusia. Tentang pencobaan Yesus oleh si Iblis, Yesus dihadapkan dengan serangkaian jalan pintas yang akan merusak kebebasan manusia. Oleh sebab itu, Yoder menempatkan ini dalam pilihan politik yang tersedia bagi Yesus. Yoder mengatakan demikian :

The temptation to use political methods of violent self-defense was one aspect of this possibility. The whole way meant the cross. For since murder is the worst sin, as it takes away freedom most utterly, so the utmost in agape is the utmost in non-self-defence, to undergo murder, respecting the other's freedom to commit the worst sin out of love for the sinner-murderer. Which is what Jesus did. ${ }^{16}$

Bagi Yoder, pencobaan Yesus menggunakan metode politik yang penuh dengan kekerasan. Sehingga seluruh jalan hidupnya adalah salib. Karena ketika pembunuhan terjadi di Alkitab, hal itu merampas kebebasan sepenuhnya. Yesus mati sebagai pengorbanan yang terbaik, justru di sanalah Tuhan mengekspresikan kasih Agape melalui kematian-Nya dengan tidakan non-resistensi (tidak ada perlawanan). Ketidakberdosaan dan ketaatan-Nya adalah apa yang Yesus tawarkan kepada Tuhan dan di dalam ketidakberdosaan itu ada kesetiaan yang mutlak untuk mencintai dan mau hidup di tengah dunia yang berdosa. ${ }^{17}$ Inilah yang menjadi titik awal dari teologi politik dari Yoder. Yoder menganggap pribadi dan tindakan Kristus, khususnya Kristus yang tersalibkan sebagai kunci untuk menafsirkan politik Kristen.

\section{Politik Yesus dan Komunitas Alternatif}

Pertanyaan yang mendasar adalah bagaimana pandangan Yoder tentang penyaliban Yesus sebagai fenomena sejarah? Hal ini penting karena penyebab penyaliban tidak dapat dipisahkan secara teologis dan historis. Memang klaim soal Yesus disalibkan untuk menebus dosa manusia menjadi realitas yang penting dalam iman orang Kristen, tetapi dosa tidak memiliki realitas yang bermakna kecuali ada dalam tindakan historis dan kongkret sebagai aksi

16 Ibid, 230.

17 Ibid.

160 Copyright (C) 2020, Dunamis, ISSN 2541-3937 (print), 2541-3945 (online) 
reaksi di dalamnya. Karena itu analisis teologis dan historis menjadi berkaitan satu dengan yang lain. Yoder memperlihatkan bahwa pelayanan Yesus adalah pelayanan yang bersifat politis. Ini tidak bisa dihindari. Dalam karya Yoder yang berjudul The Politics of Jesus, Yoder menunjukkan sifat politis dari banyak pelayanan Yesus dan relevansinya untuk zaman sekarang. Misalnya dua contoh terkait dengan pelayanan Yesus adalah, pertama, Yoder menggambarkan tahun Yobel yang dipengaruhi oleh "Manifesto Nazaret" dalam Lukas 4 sebagai restrukturisasi ekonomi, sosial, dan politik yang terlihat dalam relasi di antara umat Allah. ${ }^{18}$ Kedua, Yoder memperlihatkan tindakan penyucian Bait Suci menjadi pengambilalihan simbolik dari orang-orang yang berkuasa yaitu upaya para Imam yang memonopoli keberadaan Bait Suci baik secara politik maupun ekonomi. ${ }^{19}$ Dalam kedua hal inilah Yoder menunjukkan adanya hal-hal yang berkaitan dengan kekuasaan dan perubahan politik.

Bagi Yoder, Yesus tidak berjalan sendirian sebagai seorang nabi yang individualistis dalam merespon perubahan politik. Justru yang dilakukan Yesus adalah membangun komunitas baru, bagaimana pelayanan Yesus berhadapan dengan orangorang yang memegang kekuasaan. Yoder mengatakan Yesus mengorganisir sebagai oposisi dalam merespons berdirinya realitas sosial yang baru. ${ }^{20}$ Yang dimaksudkan oleh Yoder adalah realitas sosisal alternatif yang bukan partai politik, tetapi tatanan sosial yang sama sekali baru yang ditandai oleh salib. Yoder mengatakan bahwa Yesus membangun komunitas yang saling berbagi dan salib menjadi puncaknya. $^{21}$ Ketika Yesus memberi makan 5000 orang (Luk. 9:10-17), Yesus tidak hanya berurusan dengan sekelompok kecil komunitas para murid, tetapi gelombang yang datang untuk melihat kerajaan (basilia to Theu) menjadi nyata. ${ }^{22}$ Secara definitif, kita melihat bahwa Yesus menolak kerajaan atau politik untuk dirinya sendiri atau untuk kepentingan pengikut-Nya. Bahkan di dalam kerumunan massa tersebut, ada pujian terhadap Yesus sebagai Musa baru, pemberi nafkah (provider) dan pemimpin yang menyejahterakan. Yoder melihat bahwa justru di sanalah Yesus memperlihatkan bahwa pelayanan-Nya akan merujuk kepada penderitaan dan murid-murid harus siap memikul salib itu. ${ }^{23}$ Di sana ada pilihan

\footnotetext{
${ }^{21}$ Ibid, 37-38.

${ }^{22}$ Ibid, 34.

${ }^{23}$ Ibid, 35.
} 
antara salib dan mahkota (cross and crown), yang tidak terletak di luar, tetapi justru ada dalam arena politik. Yesus menempatkan dirinya untuk melawan Saduki dan pihak-pihak Herodian yang saat itu bekerja sama dengan Roma untuk melanggengkan kekuasaan mereka. Yesus juga menolak strategi untuk menarik diri dari hingar bingar politik seperti kaum Eseni atau kesalahen yang bersifat pribadi (orang Farisi). Cara yang diusung oleh Yesus adalah jalan salib yang justru beresiko dan berbahaya.

\section{Murid yang Radikal dan Solidaritas}

\section{Terhadap Korban}

Salib digambarkan secara politis sebagai tindakan kekejaman yang dilakukan dalam rangka untuk menjaga teritori dan wilayah kekuasaan. Bagi Yoder, menggunakan salib sebagai subjek (pengabdian) adalah tindakan memasuki area berbahaya, penuh resiko dan menjadikan Tuhan terlibat dalam penderitaan itu. Salib harus dilihat sebagai protes terhadap penderitaan dan ketidakadilan. Sebuah protes dimana Tuhan berpartisipasi dalam situasi kengerian yang dialami oleh manusia. Konteks yang terjadi dalam teologi politik salib adalah penyaliban jutaan orang, dimana terdapat dominasi sistem ekonomi dan politik yang destruktif. Dampaknya adalah marjinalisasi dan perendahan harkat martabat kemanusiaan sebagai minoritas. Oleh sebab itu, teologi politik salib adalah teologi yang tidak hanya diarahkan pada arena kekuasaan, tetapi juga di antara para korban yang rentan karena menghadapi kebijakan yang diskriminatif. Sehingga teologi salib harus bersifat lokal dan kontekstual, yang berbicara kepada para korban secara langsung. Yoder bersikeras bahwa penggunaan istilah "memikul salib" bukan dalam pengertian bertahan dalam kesengsaraan karena penyakit atau ketidakberuntungan, tetapi lebih merujuk kepada kualitas iman karena ketidaksesuaian dengan dunia. ${ }^{24}$ Bagi Yoder, salib ini bukan menanggung penyakit atau malapetaka, penderitaan yang tak terduga baik secara pribadi atau dalam bentuk kekacauan spiritual, sebaliknya salib ini adalah realitas sosial dimana tatanan baru akan datang. ${ }^{25}$ Salib sebagai seorang Kristen adalah jalan yang beresiko karena ketidaksesuaian dengan dunia yang dihadapi. Dampaknya adalah penderitaan dan penganiayaan sebagai seorang Kristen yang berhadapan dengan tatanan lama. ${ }^{26}$ Yoder memberi peringatan serius kepada gereja kontemporer bahwa salib Kalvari adalah

${ }^{26}$ Ibid.

${ }^{24}$ Ibid, 96. 
hasil politik. Jadi panggilan murid Kristus adalah sebuah harga ketidaksesuaian sosial dan politik, di mana secara sadar Yesus juga memilih jalan ketidaksesuaian itu. Penderitaan terjadi bukan karena kelemahan psikis/kekalahan dalam pengertian fisik, tetapi respon terhadap ketidakadilan. Hal ini yang menandai bahwa Yoder menekankan pilihan yang sadar dari jalan kesetiaan yang rentan dan ini adalah pemuridan yang mahal.

\section{Jalan Pasifis (Non-Violence)}

Pertanyaannya adalah bagaimana teologi salib merespon tentang kekerasan? Kontribusi Yoder yang paling signifikan terhadap etika politik Kristen adalah menghidupkan kembali tradisi pasifis. Gaya sosial yang ditandai dengan adanya komunitas baru dan penolakan kekerasan dalam bentuk apapun. Hal ini didasarkan pada salib sebagai kekuatan Allah untuk orang-orang beriman, istilahnya adalah Agnus Noster, eum Sequamur. ${ }^{27}$ Ketika Yesus ada di taman Getsemani, diperhadapkan pada pemberontakan bersenjata, jalan Yesus adalah pasifis. Yesus justru memilih jalan yang absolut, yaitu menggunakan jalan tanpa kekerasan. Jalan yang ujungnya adalah penyaliban. Yoder mene- kankan bahwa tanpa kekerasan adalah prinsip yang mutlak, bukan hanya taktik strategi semata. Yang terpenting adalah ketaatan yang mencerminkan karakter Tuhan dan bukan pada perhitungan efektifitas pengaruh/jabatan dalam kekuasaan. Penderitaan bukanlah taktik, tetapi tanda kesetiaan pada karakter Illahi. Yoder mengatakan bahwa kesetiaan yang terwujud adalah ketika pekerjaan Tuhan selaras dengan kemenangan Anak Domba. ${ }^{28}$ Pasifisme Yoder memang bertumpu pada doktrin Allah sebagai pembawa damai, tanpa kekerasan dan non-koersif.

Salib memang merujuk sebagai tanda non-kekerasan, tetapi Yoder melangkah lebih jauh dalam memperlakukan salib sebagai tanda non-perlawanan. Bagi Yoder, relasi dengan negara/pemerintah adalah kepatuhan. Panggilan orang Kristen adalah tidak menentang negara yang berlaku otoriter, tetapi upaya perlawanannya adalah dengan cara menolak pembalasan dengan kekerasan. ${ }^{29}$ Hal ini bagi Yoder disebut sebagai bentuk perlawanan Kristen. Perjuangan salib bagi Yoder adalah perjuangan non-koersif politik yang sejalan dengan keseluruhan teologinya yaitu teologi tentang perdamaian. Non-koersif memer-

\footnotetext{
${ }^{29}$ Ibid, 202.
}

\footnotetext{
${ }^{27}$ Ibid, 242.

${ }^{28}$ Ibid, 237.
} 
lukan bentuk tanggung jawab Kristen yang sangat berbeda.

\section{Relasi Gereja-Negara dan Kebangkitan Kristus}

Yoder mengartikan salib sebagai jalan yang benar, yang berbeda dengan kekuasaan Konstantin yang mana secara sistematis menggambarkan gereja yang cenderung untuk mengambil posisi kekuatan politik dan hak istimewa. Istilahnya adalah menyandang sebutan gereja negara. Oleh sebab itu, tugas orang Kristen dalam politik adalah untuk bertahan dalam solidaritas dan persekutuan dengan orangorang yang menderita. Sebaliknya gereja Konstantin adalah gereja yang membentuk aliansi dengan mereka yang memegang kekuasaan dan untuk menentukan arah masyarakat dengan cara membangun kerajaan dunia dan bukan Kerajaan Allah. Bagi Yoder, tanggung jawab utama gereja adalah menjadi gereja. Sedangkan gereja Konstantin bertumpu pada tanggung jawab, dengan menggunakan kekuatan, jika perlu dengan paksaan/kekerasan.

Gereja bagi Yoder memang entitas yang terpisah dengan negara, tetapi ada relasi yang dialektis di antara keduanya. Intinya adalah perselisihan Yoder dengan

\footnotetext{
30 Stanley Hauerwas, Vision and Virtue (Notre Dame: University of Notre Dame Press, 1981), 212.
}

Konstantin tampaknya adalah terkait dengan penggunakan kekuatan yang koersif dan sering kali berlaku keras sebagai tujuan yang dibenarkan dalam cinta Tuhan. Bagi Yoder, gereja yang menghayati salib harus menghindari dan menolak kekerasan karena tidak sesuai dengan injil. Biarlah gereja tetap menjadi gereja dan menjalani kehidupan dengan setia dan konsisten sebagai saksi. Kritik Hauerwas kepada Yoder adalah ketika "gereja biarlah tetap menjadi gereja" menyebabkan gereja tidak memenuhi tanggung jawab sosialnya dan secara spesifik tidak menyinggung kepada struktur sosial masyarakat. ${ }^{30}$ Artinya dengan tetap menjadi dirinya sendiri, gereja tidak memiliki kekuatan yang mampu menjadi agen perubahan sosial. Bagi Yoder, masalahnya adalah bukan soal apakah orang Kristen harus bertanggung jawab atau tidak, tetapi bentuk tanggung jawab apa yang diambil dalam terang tindakan Allah dalam Kristus? Contoh yang paling jelas adalah ketika persoalan gereja dan Nazi di Jerman. Gereja yang mengaku dengan gigih menentang upaya Hitler adalah justru gereja yang terpanggil dalam gereja salib. Banyak gereja saat itu yang justru terkooptasi dan tidak konsisten di dalam panggilan kesaksiannya. Yoder mengatakan bahwa peran 
gereja adalah komunitas salib yang menderita dan bersaksi dengan sabar sebagai agen yang berasal dari Allah.

Dalam analogi Martin Luther King, gereja semata-mata menjadi termometer yang mencerminkan suhu masyarakat. ${ }^{31}$ Artinya gereja sebagai tempat yang mengendalikan suhu supaya masyarakat menjadi baik, tidak destruktif dan penuh cinta damai. Bedanya Yoder dengan etika Kristen yang realis adalah bahwa kelompok realis berusaha untuk memajukan politik Kristen melalui interaksi yang erat dengan orang-orang yang memegang kekuasaan, sebaliknya Yoder berkonsentrasi kepada gereja. Gereja yang membangun komunitas seperti Kristus dan menolak untuk berpartisipasi dalam tindakan-tindakan yang melanggar esensi Injil yaitu kekerasan. Kesaksian pasifis Kristen harus bersifat teologi dan pertama-tama diarahkan kepada gereja. ${ }^{32}$ Gereja adalah gereja dalam solidaritas dan persatuan dengan Kristus, bukan gereja parasit dalam interaksinya dengan negara. Gereja secara teologis berperan sebagai katalisator perdamaian, rekonsiliasi umat manusia kepada Allah dan menjaga kemurnian serta kesaksiannya. Orang Kristen tidak boleh acuh tak acuh terhadap

\footnotetext{
${ }^{31}$ Martin Luther King, A Testament of Hope: The Essential Writings of Martin Luther King Jr (San Francisco: Harper and Row, 1986), 300.
}

politik dunia tetapi kekuatannya adalah kekuatan hamba. Kekuatan yang berasal dari pemberian diri Sang Kristus yang tersalib, memberdayakan kesabaran dan menunjukkan kegigihan dan penderitaan. ${ }^{33}$ Bagi Yoder, penderitaan memiliki makna sebagai tanda partisipasi dalam kehadiran Ilahi. Pasifisme salib bukanlah pilihan atau taktik belaka, tetapi partisipasi dalam cinta dan karakter Allah sebagaimana diwujudkan dalam Kristus. ${ }^{34}$

Lalu pertanyaannya adalah bagaimana memahami kebangkitan Kristus dalam gagasan teologi politik Yoder? Bagi Yoder, penyaliban dan kebangkitan bersifat historis, dalam arti terjadi pada waktu dan tempat tertentu. Selain itu juga bersifat meta-historis karena Kristus yang tersalib, bangkit, dan pekerjaan Roh Kudus melanjutkan realitas Kristus di masa sekarang. Setiap perubahan yang membebaskan, menyelamatkan, dan memanusiakan dalam sejarah manusia adalah tindakan Allah. Apa relevansinya kebangkitan Kristus ini untuk teologi politik? Pertama, kebangkitan meratifikasi (mengesahkan) makna salib. Tindakan Yesus non-kekerasan adalah pilihan politik yang mengarah kepada salib. Jadi seperti ada legitimasi Illahi. Orang-

\footnotetext{
${ }^{32}$ Yoder, The Politics of Jesus, 240.

${ }^{33}$ Ibid, 96.

${ }^{34}$ Ibid, 240.
} 
orang yang rela mati seperti Yesus melihat dengan jelas, bahwa mereka dibenarkan dalam narasi besar antara salib dan kebangkitan. Kedua, kebangkitan bukan hanya kebangkitan orang yang sudah mati, tetapi juga kebangkitan pembenaran korban. Oleh karena itu, ada harapan bagi para korban penderitaan sebab Tuhan ada di pihak mereka. Ketiga, kebangkitan membuka kemungkinan untuk kekuatan baru bagi perdamaian dunia. Apapun situasi penyaliban, selalu ada kemungkin baru tentang kebangkitan dan itu menimbulkan harapan. Keempat, salib dan kebangkitan menunjukkan sisi solidaritas Allah. Orang yang tersalib merasakan belarasa Allah dan merasakan kuasa Illahi yang membangkitkan. Belarasa yang radikal dari Allah tidak dapat dikalahkan oleh kematian, tetapi memiliki kemenangan iman. Kelima, kebangkitan membawa pada masa depan. Seorang Kristen yang hidup dalam kondisi penyaliban, namun hidup dalam terang kebangkitan akan memiliki masa depan Allah yang adil ke dalam realitas masa kini.

\footnotetext{
35 Andreas A. Yewangoe, "Membangun Teologi Bencana," in Teologi Bencana: Pergumulan Iman Dalam Konteks Bencana Alam Dan Bencana Sosial,
}

Implikasi Theo-Politik Salib John Howard Yoder: Tragedi, Penderitaan Allah dan Masyarakat Indonesia

Gagasan Yoder tentang theo-politik salib tersebut memiliki implikasi yang berharga bagi teologi kontekstual di Indonesia. Kita mengenal Andreas A. Yewangoe yang berbicara tentang salib dalam konteks multi agama dan penderitaan yang tidak adil di Indonesia. ${ }^{35}$ Penderitaan komunitas Kristen menjadi dasar untuk berteologi dalam konteks salib Kristus. Komunitas Kristen yang beralih dari perasaan takut dan kebencian menuju keberanian serta kemampuan untuk hidup bertahan pasca kekerasan. Komunitas yang bergulat antara penderitaan dan pengorbanan sebagai akibat dari kekerasan kolektif sepanjang era Orde Baru. Dengan menggunakan simbol salib, komunitas Kristen merespon pemulihan dan rekonsiliasi antar agama, dan salib menjadi sarana untuk komunikasi sosial sebagai tindakan politik non-kekerasan. Yewangoe menyebut pentingnya salib sebagai respon Kristen yang relevan dalam konteks ketidakadilan dalam masyarakat pluralistik, konsep yang saling terkait antara korban (victim) dan kurban (sacrifice). Teologi

ed. Ati Hildebrant Rambe, Markus Hildebrant Rambe, and Jilles DeKlerk (Makassar: Oase INTIM, 2006), 221-251. 
tentang salib dikembangkan untuk membawa narasi korban kekerasan dan dimensi pengorbanan mendapat tempat di ruang publik.

Pendekatan Yewangoe dalam refleksinya adalah dengan memodifikasi teologi salib dari fokus teologi penghukuman Allah kepada teologi penderitaan Allah. $^{36}$ Dalam refleksinya, Yewangoe menghubungkan penderitaan Allah terhadap kemampuan komunitas untuk menanggung penderitaan tanpa harus menanggung kesalahan atau dosa. Yewangoe memutus teologi hukuman dan beralih kepada tanggung jawab manusia atas alam dan solidaritas. ${ }^{37}$ Selain itu, Yewangoe juga menggambarkan tentang respon atas kesaksian para perempuan korban yang selamat dari perkosaan oleh tentara militer. ${ }^{38}$ Dalam kesaksian itu, teologi salib ditantang sekaligus digugat atas relevansi kekerasan selama ini. Itu artinya, teologi harus memberikan kesaksian atas respon ketidakadilan yang selama ini berlangsung di era Orde Baru. Yewangoe memberikan catatan rumitnya para perempuan korban 1998 dalam memposisikan teologi salib di tengah persimpangan sejarah penindasan militer Indonesia dan perjuangan perem-

\footnotetext{
${ }^{36}$ Ibid, 221-251.

${ }^{37}$ Ibid, 246-249.

${ }^{38}$ Ibid.

${ }^{39}$ Ibid.
}

puan untuk menyuarakan fakta dan kebenaran. Dalam refleksi Yewangoe, teologi salib harus menunjukkan kesaksian tentang penderitaan dan nilai-nilai Kristiani dalam menghadapi hidup di tengah realitas kekerasan dan ketidakadilan yang "tidak berwajah.” Bagi Yewangoe, salib menjadi relevansi simbol Illahi yang menderita di tengah penderitaan korban baik sosial/ politik dan bencana alam. ${ }^{39}$ Oleh sebab itu, narasi salib dapat menjadi kerangka teologis yang menandai dimensi kematian dan pengorbanan, dan terkait dengan proses penyembuhan dalam semangat kegigihan untuk menghadapi penderitaan hidup sehari-hari di tengah masyarakat.

Dalam bukunya yang berjudul Trauma and Grace: Theology in a Ruptured World, Serene Jones mengatakan bahwa komunitas Kristen dapat membangun imajinasi penyaliban (crucified imaginings). ${ }^{40}$ Narasi Kristen kental dengan gagasan salib yang terluka (the broken cross), salib sebagai cermin (the mirrored cross), dan salib yang kosong (the empty cross). Di dalam konstruksi tersebut relasi terjadi antara kekerasan, kematian (death), trauma dengan anugerah, harapan dan kehidupan di dalam narasi komunitas. Pandangan ini

\footnotetext{
${ }^{40}$ Serene Jones, Trauma and Grace: Theology in a Ruptured World (Louisville: Westminster John Knox Press, 2009), 70-75.
} 
menantang identifikasi salib yang merujuk kepada penyalahan korban (victimization). Imajinasi orang Kristen tentang salib dapat menjadi gambaran umum tentang simbol pengorbanan dan kemenangan di tengahtengah realitas kekerasan. Jones mengatakan demikian :

Kesaksian para korban yang selamat adalah suara orang yang mengalami penderitaan yang sebelumnya tidak terkatakan. Kesaksian itu masuk dan saling menerima serta mengkonfirmasi bahwa suara orang yang selamat didengar dan tragedi yang kelam tidak perlu lagi disembunyikan di sudut jiwa yang pekat, tetapi dapat ditarik dalam cahaya hati sebagai kenyataan yang layak untuk dipertahanan, Oleh sebab itu, dengan berbagi kisah pengharapan adalah perjuangan membangun kepenuhan hidup di masa depan..$^{41}$

Oleh sebab itu, dalam konteks pasca kekerasan sekarang, kebutuhan yang signifikan sebagai gereja dalam membangun etika politik adalah bersaksi dan menyaksikan apa yang terjadi dalam kehidupan mereka. Kesaksian untuk melanjutkan kehidupan bersama dengan umat muslim dan agama lain sebagai sesama di tengah masyarakat. Masyarakat membutuhkan ruang untuk berbagi suara para korban ketidakdilan dan penderitaan. Gereja sebagai

\footnotetext{
${ }^{41}$ Ibid, 54.

${ }^{42}$ Emanuel Gerrit Singgih, "Allah Dan Penderitaan Di Dalam Refleksi Teologis Rakyat Indonesia: Sebuah Evaluasi Teologis," in Teologi Bencana:
}

rumah doa dapat menjadi ruang untuk berbagi para saksi yang saling memulihkan dan rekonsiliasi antar umat beragama.

Salib menjadi simbol utama yang secara kolektif merujuk kepada memori kekerasan. Teologi salib menyediakan cara yang mungkin bagi masyarakat untuk bertahan bersama dengan narasi penderitaan dan kelangsungan hidup di masa yang akan datang. Refleksi Yewangoe adalah Allah yang menderita ada bersama-sama dengan orang yang menderita. Gerrit Singgih juga berbicara soal yang sama bahwa teologi salib harus dipertahankan sebagai alternatif teologi hukuman. ${ }^{42} \mathrm{Se}$ perti halnya kasus komunitas Kedungombo di Jawa Tengah yang ditolak hak-haknya oleh rezim orde baru, pada tahun 1980-an, masyarakat justru menemukan motivasi yang kuat untuk memperjuangkan hak-hak mereka. Singgih menyarankan untuk menempatkan pertanyaan mengapa dalam pertanyaan Yesus sendiri di atas kayu salib, di mana memungkinkan orang-orang yang menderita menemukan makna atas penderitaan mereka. Refleksi ini mengarah kepada solidaritas kepada orang lain yang menderita dan berjuang untuk mengatasi

Pergumulan Iman Dalam Konteks Bencana Alam Dan Bencana Sosial, ed. Ati Hildebrant Rambe, Markus Hildebrant Rambe, and Jilles DeKlerk (Makassar: Oase INTIM, 2006), 253-269. 
penderitaan tersebut. ${ }^{43}$ Teologi salib menjadi tema teologis yang penting dalam pencarian komunitas Kristen Indonesia untuk memberi makna di tengah tragedi kekerasan. Yewangoe menekankan bahwa refleksi salib ditempatkan dalam narasi inkarnasi, sebuah perjalanan Allah menjadi manusia untuk memberi ruang kehidupan di tengah dunia ini. ${ }^{44}$ Sedangkan Singgih melihat teologi salib harus ditempatkan dalam teologi Paskah. ${ }^{45}$ Tentunya, hal ini menjadi peristiwa yang monumental bahwa salib menjadi simbol yang memberi kekuatan dalam menghadapi kekerasan. Oleh sebab itu, salib menjadi manifestasi kekerasan, penderitaan, pengorbanan dan kelangsungan hidup yang menjadi bagian realitas bangsa Indonesia, khususnya komunitas Kristen.

Paulus S. Widjaya juga mengungkapkan bahwa politik salib Yoder ini memberikan sumbangsih untuk teologi politik di Indonesia yaitu politik pelayanan dan politik doksologi (kepercayaan). ${ }^{46}$ Hal ini terjadi karena politik di Indonesia dipengaruhi oleh teologi sukses. Ulasan dari Widjaya menunjukan, pertama, teologi

\footnotetext{
${ }^{43}$ Ibid, 267.

${ }^{44}$ Yewangoe, "Membangun Teologi Bencana," 249.

45 Singgih, "Allah Dan Penderitaan Di Dalam Refleksi Teologis Rakyat Indonesia: Sebuah Evaluasi Teologis," 268.

46 Paulus Sugeng Widjaja, "Membangun Teologi Politis Di Indonesia (Dari Teologi Sukses Ke Politik
}

sukses politik tercipta karena pemahaman yang keliru tentang berkat Tuhan. Kedua, teologi sukses politik juga tercipta karena adanya pragmatisme yang naif. Ketiga, teologi sukses politik juga tercipta karena adanya optimisme yang berlebihan akan peran negara untuk membentuk masyarakat yang lebih baik. $^{47}$ Justru yang perlu dikembangkan di Indonesia adalah politik pelayanan, seperti Yesus yang melayani sebagai hamba menderita (jalan salib) dan bukan kekuasaan yang dominatif. Kekuasaan diganti dengan kuasa kelemahlembutan, kesabaran dan pelayanan. Widjaya mengatakan bahwa politik pelayanan sangat membantu kita karena politik tersebut mendorong kita untuk menempatkan diri dalam posisi, bukan sebagai orang yang berkuasa, tapi sebagai orang yang lemah yang tidak mampu mencegah dan menghentikan kejahatan yang terjadi di dunia. ${ }^{48}$ Sedangkan politik doksologi adalah aktifitas yang bukan memimpin dan mengendalikan dunia, melainkan aktifitas untuk memuliakan Tuhan. ${ }^{49}$ Teologi ini bersumber dari politik Yesus, dimana jalan yang dituju adalah

Pelayanan Dan Doksologi)," Gema Teologi: Jurnal Teologi Kontekstual 59 (2004): 51-63, accessed October 23, 2020, http://journal-theo.ukdw.ac.id/ index.php/gema/article/view/236.

${ }^{47}$ Ibid.

${ }^{48}$ Ibid.

${ }^{49}$ Ibid. 
jalan salib dan bukan jalan pengejaran jabatan kekuasaan.

Politik Yesus, Sang Liyan (The Others), dan Dialog Inter-Religious: Sumbangsih Wajah Gereja di Indonesia (From Conservatives Turn to Non-Violence)

Di Indonesia, agama dan perangkat simbol-simbolnya dapat dengan mudah ditarik ke dalam perebutan kekuasaan. Malahan agama menjadi identitas pembeda yang saling meniadakan, semacam politik peniadaan (exclusion-politics) bagi sang liyan (the others). Conservatives turn menjadi sarana lahirnya benih-benih dan tindakan diskriminatif. Ciri utama dari keyakinan teologis diskriminatif ialah seseorang yang beriman dan/atau komunitas iman tertentu selalu mengalami gangguan mental fobia, paranoid dan reaksioner. Selalu merasa curiga terhadap orang lain dan komunitas lain. Kehadiran orang lain (the other) dengan identitasnya sendiri selalu dipandang sebagai ancaman.

Bicara tentang yang lain (liyan), di dalam PB, "Yesus sebagai Allah" adalah kristologi yang sangat ditekankan oleh Injil Yohanes. Berbeda dengan pemaparan Injil Matius dan Lukas tentang asal-usul keturunan Yesus, yang melihat dari konteks
Nazareth (kemanusiaan Yesus). Injil Yohanes tidak menekankan asal-usul duniawi Yesus sebagai hal yang utama. Yesus adalah Ia yang datang dari atas, dari Surga, dari Bapa. ${ }^{50}$ Hal ini diucapkan sendiri oleh Yesus menurut Yoh. 8:23, "Kamu berasal dari bawah, Aku dari atas; kamu dari dunia ini, Aku bukan dari dunia ini," dan ayat 42, "Jikalau Allah adalah Bapamu, kamu akan mengasihi Aku, sebab Aku keluar dan datang dari Allah. Dan Aku datang bukan atas kehendak-Ku sendiri, melainkan Dialah yang mengutus Aku." Inilah cara Injil Yohanes untuk mengatakan betapa uniknya hubungan Yesus dengan Allah dan betapa asingnya dunia ini terhadap Allah dan Yesus. Menurut penulis, inilah status keasingan pertama Yesus, yang secara sadar atau pun tidak diakui, bahkan diimani oleh para pengikut-Nya.

Sedangkan dalam Injil Matius, kita melihat bahwa sejak kelahiran Yesus dan asal-usul keturunan-Nya, ada orang-orang asing (orang-orang yang mengalami diskriminasi) tercatat dalam penulis Injil, mulai dari Tamar (Mat. 1:3), Rahab, Rut (Mat. 1:5), istri Uria (Mat. 1:6), dan Maria (Mat. 1:16). Orang-orang yang termarjinalkan secara identitas tetapi mendapat ruang dan

\footnotetext{
50 John P. Meier, A Marginal Jew: Rethinking the Historical Jesus (New York: Doubleday, 1991), 215.
} 
disebut dalam daftar keturunan Yesus. Bahkan yang menarik adalah penyebutan Rahab dan Rut (non-Yahudi) masuk di dalam daftar silsilah. Itu artinya, orangorang asing juga diperlakukan setara oleh Yesus dan penulis Alkitab, meskipun kita tahu bahwa teks-teks Injil adalah teks-teks yang sangat kuat dalam budaya patriaki dan Yudaisme. Hal ini memperlihatkan bahwa sejak awal misi penyelamatan Allah, juga mencakup orang-orang non Yahudi. Seorang teolog yang bernama John P. Meir mengatakan bahwa Yesus sendiri adalah (keturunan) orang asing, yang sebenarnya secara historis bukan keturunan biologis Yusuf. ${ }^{51}$ Meir ingin mengatakan bahwa Yesus memiliki keasingan dalam status identitasnya. Jika Injil Yohanes adalah produk konflik Kristen-Yahudi, maka Yesus dijelaskan datang dari atas, bukan dari bawah. Di Injil-injil sinoptik Yesus jelas rabbi Yahudi, hanya saja keberadaanNya adalah sebagai guru keliling, yang tidak mempunyai tempat tetap, dan kota kelahiran-Nya, Nazaret, pun menolak Dia.

Yesus dalam kehidupan dan pelayanan-Nya selalu menunjukkan keterbukaan dan inklusivitasnya terhadap orang lain (liyan). Salah satu contohnya adalah penerimaan dan keterbukaannya terhadap orang Samaria. Orang Samaria dipandang rendah oleh orang-orang Yahudi dan bagi orang Yahudi kelompok yang layak disebut sebagai anak-anak Abraham hanyalah kelompok yang termasuk prototipe Yahudi dan orang Samaria tidak termasuk dalam kelompok tersebut. Mereka diasingkan oleh orang-orang Yahudi. Sikap Yesus terhadap orang Samaria begitu luar biasa. Misalnya di dalam perumpamaan orang Samaria yang baik hati (Luk. 10:30-36), Yesus menunjukkan belas kasih dan murah hati terhadap orang asing. Justru Yesus menjungkirbalikkan pandangan Yahudi bahwa orang yang dianggap asing justru yang menunjukkan arti mengasihi kepada sesama. Bahkan yang menarik di dalam Yohanes 8:48 dikatakan, "Orang-orang Yahudi menjawab Yesus: "Bukankah benar kalau kami katakan bahwa Engkau (Yesus) orang Samaria dan kerasukan setan?" Ini adalah ayat yang memperlihatkan penghinaan orang Yahudi kepada Yesus yang bertujuan untuk menolak kehadiran-Nya. Jawaban Yesus, "Aku tidak kerasukan setan, tetapi Aku menghormati Bapa-Ku dan kamu tidak menghormati Aku." Dalam teks ini, ada afirmasi bagi keasiangan-Nya di mata mereka yang menolak Dia.

\footnotetext{
${ }^{51}$ Ibid, 217.
} 
Yang menarik di dalam Matius 25:31-46 Yesus berkata, "Sebab ketika Aku lapar, kamu memberi Aku makan, ketika Aku haus, kamu memberi Aku minum, ketika Aku seorang asing, kamu memberi Aku tumpangan..." (Matius 25 : 35). Teks ini memperlihatkan tidak hanya sikap yang baik terhadap orang asing (liyan), tetapi Yesus justru mengidentifikasikan diri-Nya sebagai orang asing. Biasanya teks ini dipahami sebagai teks untuk berbagi kepada orang-orang marjinal, yang cenderung menempatkan posisi superior kepada sang pemberi. Yesus mengubah status keasingan menjadi positif, khususnya orang-orang yang ada dalam status yang terpinggirkan di dalam masyarakat. Bahkan di dalam kisah kebangkitan-Nya ketika berjumpa dengan Kleopas dan temannya (Luk. 24:13-35), Yesus tampak sebagai orang asing, tetapi dalam perjumpaan ada hospitalitas satu dengan yang lain. Saat ada di rumah Kleopas, memecah roti dan berbagi, Yesus yang asing (tamu) berubah menjadi sang tuan rumah. Yesus yang diundang oleh Kleopas bukan Yesus yang superior terhadap yang lain. Ia menghormati dan tidak merasa diri-Nya penting. Dalam perjumpaan itu, ada berkat yang saling dipertukarkan.

Menurut penulis, dalam membangun gagasan teologi politik di mana bangsa Indonesia ada dalam babak reformasi ini diperlukan adanya keseimbangan antara teologi politik yang bersumber pada nilai-nilai Alkitabiah seperti politik salib John Howard Yoder dan konteks/ situasi diskriminasi riil di tengah masyarakat. Kajian teologis kita perlu mengedepankan theo-politik Yesus yang nir-kekerasan dan dialog inter-religius dalam membangun iman yang membumi. Nilai Kristiani tidak hanya dicari di dalam alam spiritual yang dianggap lepas dari dunia tetapi justru di tengah dunia, di bumi yang kongkret. Iman kepada Yesus yang tersalib adalah iman yang membumi. Iman yang melihat bahwa Yesus yang tersalib juga ada di dalam penderitaan masyarakat Indonesia. Gereja dipanggil untuk menghayati keasingan (the others) dalam wajah yang terbuka dan inklusif. Dalam keasingan tersebut, ada penggalian makna tentang penderitaan Kristus yang tersalib, seperti uraian John Howard Yoder di tengah konteks Indonesia. Sehingga mentalitasnya adalah bukan mentalitas untuk membangun relasi atas perasaan syndrom minoritas, tetapi keterbukaan iman yang mendalam dalam perjumpaan sebagai murid yang radikal.

Catatan penulis adalah pertama, isu/sentimen agama merupakan "duri dalam daging." Sewaktu-waktu dapat dieksploi- 
tasi oleh politisi petualang. Politisasi agama diruang publik sebagai mode produksi yang menjanjikan keuntungan finansial. Komoditas agama menjadi jualan politik. Layaknya sebagai sebuah pasar. Produsen (elit politisi), pembeli (masyarakat), barang dagangan (isu SARA), dan keuntungan. Masyarakat berperan sebagai pembeli yang terpesona oleh isu politik yang dibungkus oleh narasi keagamaan (investasi akhirat) menjanjikan pahala dan surga. Di situlah bahaya besar terjadi yaitu persekongkolan cemar. Mempersekongkolkan agama dan politik. Iman dan kuasa. Altar dan Tahta. Agama dipolitisasi dan ujung ujungnya adalah perebutan ekonomi. Kedua, mentalitas polaristik, saya adalah komunitas anak Allah - mereka kumpulan anak Iblis. Orang lain (agama lain) dipandang sebagai musuh, yang dibenci dan ditaklukkan. Kita yang mayoritas atau "kita" orang normal pantas untuk disukai dan "mereka" pantas untuk dibenci adalah teologi yang sehari-hari dihidupi oleh kaum awam sehari-hari. Ketiga, relasi agama dan negara. Relasi berbeda, namun tidak terpisah, sehingga sebenarnya agama bisa berperan untuk mendinamiskan negara. Agama bisa memberikan wawasan yang luas (membebaskan negara dari stagnasi). Agama memberi arah dan dinamika - menjadi fungsi kritis. Supaya agama tidak terjebak dalam fungsi ideologis yang memberi legitimasi status $q u o$. Oleh sebab itu yang dibutuhkan adalah negarawan-negarawan (bukan politisi) yang mampu berdialog dengan kaum agamawan. Para negarawan menimba wawasan dari agama. Sebaliknya kaum agamawan terlibat dalam sosial kemasyarakatan. Sehingga agama menjadi membumi. Keempat, penegasan konstitusi yang menjadi konsesus bersama seringkali tidak terwujud dalam kebijakan-kebijakan publik. Naasnya, kebijakan yang diskriminatif dan mengusung ekstrimisme religius tampil lewat wajah konstitusional.

Dari catatan-catatan di atas, maka pertama, kita perlu menjadi gereja yang menghidupkan suara kenabian, kritis dalam kehidupan bermasyarakat, berbangsa, dan bernegara melalui mentalitas dan dasar sebagai pengikut Yesus/murid yang radikal, sehingga ada kepekaan dalam persoalan diskriminasi dalam segi apapun baik agama, etnis dan kelompok yang berbeda. Kedua, mengembangan teologi interreligius dialogue yang otentik, tulus dan bersahabat (hospitality), supaya kaca mata kita sebagai gereja (orang Kristen) tidak melihat agama lain sebagai musuh/ ancaman, tetapi positif di dalam membangun masyarakat sipil di tengah masyarakat majemuk. Jadi intinya adalah pembangunan civil society bukan dalam 
rangka teokrasi Kristen, tetapi dilakukan oleh pelbagai keagamaan yang berbeda di Indonesia.

Dengan membangun kepelbagaian agama dan menghargai nilai-nilai agama lain dalam civil society, maka yang terjadi adalah iman Kristen kita justru diperkaya. Wajah gereja ke depan di era reformasi ini adalah model perjumpaan yang ramah (hospitality) dalam menyumbangkan mutu kehidupan di tengah bangsa dan negara. Sehingga nilai-nilai persaudaraan dan perdamaian menjadi nilai yang serius dalam perjuangan bersama. Oleh karena itu, diperlukan teologi politik salib yang membangun jembatan dan bukannya tembok. Dialog inter-religius yang terjadi adalah dialog iman dan kehidupan, bagaimana setiap umat lintas budaya dan agama membicarakan dan mengungkapkan pengalaman iman serta penghayatannya untuk kehidupan bersama. Dari sini, terdapatlah transformasi iman dan kesadaran untuk tumbuh dengan lebih baik. Dengan demikian, gereja memiliki panggilan dari the other (sang asing), rentan dan terluka untuk memulihkan dan membangun komunitas yang lebih manusiawi (non-violance).

\section{KESIMPULAN}

Konservatisme agama (conservative turn) telah menumbuhkan benih-benih ke- kerasan atas nama agama. Kesadaran yang terbangun di dalamnya adalah kesadaran yang bersifat triumfalistik, yang mengekslusi sang liyan melalui agama sebagai identitas pembeda. Sebaliknya, teologi salib membangun kesadaran baru. Melaluinya dibangun suatu komunitas alternatif yang ramah dan solider kepada mereka yang termajinalkan, namun nir-kekerasan dalam perjuangannya melawan kesadaran yang menindas.

\section{DAFTAR PUSTAKA}

Hasan, Noorhaidi. Laskar Jihad: Islam, Militancy, and the Quest for Identity in Post-New Order Indonesia. New York: Southeast Asia Program Cornell University, 2006.

Hauerwas, Stanley. Vision and Virtue. Notre Dame: University of Notre Dame Press, 1981.

Hefner, Robert W. Civil Islam: Muslims and Democratization in Indonesia. Princeton and Oxford: Princeton University Press, 2000.

Jones, Serene. Trauma and Grace: Theology in a Ruptured World. Louisville: Westminster John Knox Press, 2009.

King, Martin Luther. A Testament of Hope: The Essential Writings of Martin Luther King Jr. San Francisco: Harper and Row, 1986.

Maghfuri, Amin. "Countering Conservative-Radical Understanding by Mainstreaming Moderat Islam and the Role of Educational Institution in Indonesia." Sunan Kalijaga International Journal on Islamic Educational Research 3, no. 1 
(December 16, 2019): 1-14. Accessed October 22, 2020. http://ejournal.uinsuka.ac.id/tarbiyah/index.php/SKIJIE R/article/view/2782.

Meier, John P. A Marginal Jew: Rethinking the Historical Jesus. New York: Doubleday, 1991.

Mietzner, Marcus, and Burhanuddin Muhtadi. "The Myth of Pluralism: Nahdlatul Ulama and the Politics of Religious Tolerance in Indonesia." Contemporary Southeast Asia: A Journal of International and Strategic Affairs 42, no. 1 (2020): 58-84. Accessed October 22, 2020. https://muse.jhu.edu/article/754323/su mmary.

Mujiburrahman. FeelingThreatened: Muslim-Christian Relations in Indonesia's New Order. Leiden: Amsterdam University Press, 2006.

Schmid, Alex P. "Moderate Muslims and Islamist Terrorism: Between Denial and Resistance." The International Centre for Counter-Terrorism - The Hague 8, no. 9 (2017). Accessed October 22, 2020. https://icct.nl/ publication/moderate-muslims-andislamist-terrorism-between-denialand-resistance/.

Singgih, Emanuel Gerrit. "Allah Dan Penderitaan Di Dalam Refleksi Teologis Rakyat Indonesia: Sebuah Evaluasi Teologis." In Teologi Bencana: Pergumulan Iman Dalam Konteks Bencana Alam Dan Bencana Sosial, edited by Ati Hildebrant Rambe, Markus Hildebrant Rambe, and Jilles DeKlerk. Makassar: Oase INTIM, 2006.

Sukamto, Amos, and Rudy Pramono. "The Roots of Conflicts between Muslims and Christians in Indonesia in 19951997." Transformation: An International Journal of Holistic
Mission Studies 37, no. 3 (July 11, 2020): 208-221. Accessed October 22, 2020. http://journals.sagepub.com/doi /10.1177/0265378820937722.

Tamawiwy, August Corneles. "Bom Surabaya 2018: Terorisme Dan Kekerasan Atas Nama Agama." GEMA TEOLOGIKA: Jurnal Teologi Kontekstual dan Filsafat Keilahian 4, no. 2 (October 16, 2019): 175-194. Accessed October 22, 2020. http://journal-theo.ukdw.ac.id/index .php/gemateologika/article/view/443.

Widjaja, Paulus Sugeng. "Membangun Teologi Politis Di Indonesia (Dari Teologi Sukses Ke Politik Pelayanan Dan Doksologi)." Gema Teologi: Jurnal Teologi Kontekstual 59 (2004): 51-63. Accessed October 23, 2020. http://journal-theo.ukdw.ac.id/index. php/gema/article/view/236.

Yewangoe, Andreas A. "Membangun Teologi Bencana." In Teologi Bencana: Pergumulan Iman Dalam Konteks Bencana Alam Dan Bencana Sosial, edited by Ati Hildebrant Rambe, Markus Hildebrant Rambe, and Jilles DeKlerk. Makassar: Oase INTIM, 2006.

Yoder, John Howard. Preface to Theology, Christology and Theological Method. Elkard: Co-op Bookstore, 1982.

- The Politics of Jesus. Grand Rapids: Eerdmans, 1994.

Yunanto, Sri. Islam Moderat vs Islam Radikal: Dinamika Politik Islam Kontemporer. Yogyakarta: Media Pressiondo, 2018.

Zuhdi, Muhammad. "Challenging Moderate Muslims: Indonesia's Muslim Schools in the Midst of Religious Conservatism." Religions 9, no. 10 (October 11, 2018): 310. Accessed October 22, 2020. http:// www.mdpi.com/2077-1444/9/10/310. 